\title{
Are troglobitic taxa troglobiomorphic? A test using phylogenetic inference
}

\author{
Laure Desutter - Grandcolas *
}

\begin{abstract}
SUMMARY
Obligate cave dwelling organisms are frequently characterised by a peculiar morphological syndrome, named troglomorphosis or troglobiomorphosis. This hypothesis, which deals with the evolutionary influence of the subterranean environment on cave organisms is far from being universally accepted. Yet it has been adopted by many authors and is often included in the definitions of the current classification of cave taxa.

In this paper I present a test of the troglobiomorphosis hypothesis, using the case study of the cricket clade Amphiacustae (Orthoptera, Grylloidea, Phalangopsidae). Such a test preliminarily requires that observations of the habitat of the taxa (achieved on present-day populations) are clearly separated from hypotheses on the evolutionary transformations of cave taxa (troglobiomorphosis hypothesis $s$. str.). The evolutionary hypotheses on troglobite morphology are tested using phylogenetic inference, that is by parsimoniously mapping the states of several morphological characters (eye size, body colour, relative hindleg size) onto the cladogram of the Amphiacustae.

According to these phylogenetic analyses, the troglobiomorphosis hypothesis is corroborated by the patterns reconstructed for eye size and body coloration characters, but is refuted by the patterns built for hindleg size.
\end{abstract}

\section{INTRODUCTION}

In the numerous studies dealing with the evolution of troglobitic life, troglobitic taxa are frequently defined as having a peculiar morphological syndrome ${ }^{1}$ named "troglomorphosis" (Barr, 1968; Ginet \& Decu, 1977; Howarth, 1983; Barr \& Holsinger, 1985; Camacho, 1992) or "troglobio-

${ }^{1}$ As data on the physiology and life history strategies of cave dwelling organisms are accumulating, although on very few species yet, characteristics other than morphological are now included in the «troglobiomorphic» syndrome (Christiansen, 1992; Thibaud, 1994). Such data are not considered here, but all the conclusions drawn from my morphological analysis apply to them, especially those concerning methodological requirements.

* U PRESA 8043 CNRS, Laboratoire d'Entomologie, Muséum National d'Histoire naturelle, 45 rue Buffon, F-75005 Paris, France.

Paper presented at the Symposium "Cave Insects and Evolution”, organised by M. Bologna and F.G. Howarth, for the XX International Congress of Entomology, Firenze, Italy, August 25-31, 1996. 
morphosis" (Juberthie \& Decu, 1994). A pale coloration, an increase of appendage size (legs, palpi, antennae...), the reduction or the loss of eyes and wings are often given as the most conspicuous morphological changes, among others, shown by "true troglobites". As emphasised by Bellès (1991: 325 ) for example, "The most peculiar cave-adapted group is, of course, that of troglobites, which have been typified by a series of morphological features, including loss or reduction of eyes, wings and cuticular pigments, and an increase of sensorial devices, often accompanied by the development of longer appendages and a more slender body form: the so-called "troglobiomorphic" characters" (italics mine). According to most authors, this is a facet of the "regressive evolution" of cave dwelling organisms (Vandel, 1964; Barr, 1968; but see Howarth, 1987; Botosaneanu \& Holsinger, 1991).

There is no existing consensus concerning the degree of generality of the troglobiomorphosis hypothesis and several authors have criticised the tendency to consider as troglobites only the taxa presenting these morphological peculiarities. As Vandel (1964: 29) stated: "Aucun critère morphologique ne peut être tenu comme strictement caractéristique des cavernicoles [restricted here to troglobites]. Tout ce que nous pouvons affirmer, c'est que certaines manifestations (en particulier, la dépigmentation et l'anophthalmie) sont statistiquement plus fréquentes chez les cavernicoles que chez les épigés" (square brackets mine). Similarly Culver (1982: 36) remarked that: "Many troglophiles have no known surface populations and are classified as troglophiles only because they show little sign of regressive evolution". Despite such facts and comments, the troglobiomorphosis hypothesis has become more and more generally used. It has been included in the most commonly used classification of cavernicolous taxa (Racovitza, 1907; Ginet \& Decu, 1977; Bellès, 1991; Peck \& Finston, $1993, \ldots$ ), although this classification was initially based solely on ecological grounds (Schiner, 1854; Vandel, 1964), or has even been used as the main criterion for classification (Christiansen, 1962).

As noted by several authors, however, this current opinion is a confusing mixture of ecological and evolutionary hypotheses, especially of those hypotheses dealing with the habitat of the taxa, their phenotypic responses to a subterranean habitat and their evolutionary transformations (Barr \& Holsinger, 1985; Bellès, 1991; Matile, 1994; Desutter-Grandcolas, 1997c). As a result none of these hypotheses can be thoroughly tested, because each hypothesis is directly linked to several others and none is independent (Eldredge \& Cracraft, 1980; Grandcolas et al., 1994). How can we test if troglobiomorphy characterises obligate cave dwelling taxa if we $a$ priori assume that troglobitic taxa are troglobiomorphic? Similarly how can we assume that a character has been modified because of cave colonisation 
if the ancestral state of this character in the clade to which the troglobitic taxa under study belong is unknown?

In order to test if troglobitic taxa are troglobiomorphic, it is necessary beforehand to clearly separate the hypotheses concerning the habitat of the taxa, and those dealing with their evolutionary transformations. The only alternative would be a non-scientific faith in current opinion and an abandon of any scientific approach on cave life analysis. Habitat characterisation results from present-day observations and is achieved through population studies. On the contrary, studies of the evolutionary history of the taxa are performed per natura in a historical perspective: this implies that the characters under study are analysed in a phylogenetic perspective (Carpenter, 1989; Brooks \& McLennan, 1991; Grandcolas et al., 1994). Habitat characterisation on one hand and evolutionary transformations of the taxa on the other are two different scientific questions, which can be studied by two different kinds of approaches, population biology and comparative biology respectively (Peck, 1981; Grandcolas et al., 1997).

Let us consider first the problem of habitat characterisation. An immediate consequence of the above is that the current classification of cavernicolous taxa needs to be modified to allow the description of the habitats of the taxa without presuming their evolutionary transformations. I have analysed this problem in another paper and proposed to classify the taxa exclusively according to their behavioural ecology (Desutter-Grandcolas, 1997c) only those taxa which live and reproduce in the subterranean environment without leaving it, should thus be qualified as troglobitic. Other taxa would be classified according to their own main habitat (straminicolous, cavicolous, dendrophilous, etc., see for example Lincoln et al., 1982), even though they may appear more or less accidentally or regularly in caves, which may represent a substitute of their habitat. For example, many nocturnal cavicolous crickets (Orthoptera, Orylloidea) use caves to hide during the day: they have been erroneously qualified as cavernicolous or troglophiles (Vandel, 1964; Leroy, 1967), but their natural habitat includes burrows or hollow trees, and they have no peculiar link with subterranean habitats. The proposed classification no more recognises so-called troglophilic or trogloxenous taxa, a source of ambiguity in many previous classifications (see comments in Christianson, 1962; Barr, 1968; Howarth, 1983; Barr \& Holsinger, 1985; Peck, 1990; Culver, 1982; Thibaud, 1994). Also it completely separates the habitat from the evolutionary history of the taxa. In fact it only requires that observations are made in the natural environment, outside caves, to check for the habitat of the taxa. This classification has been used for example to clarify the list of cave living crickets (Orthoptera, Grylloidea) (Desutter-Grandcolas, 1997a; see also DesutterGrandcolas, 1993, 1995a) and is adopted in the present paper. 
The second problem is to study the evolutionary transformations of troglobitic taxa. In order to build sound hypothesis on character transformation, one needs to know which are the ancestral states of the characters and how the characters have evolved in the clade under study (polarity of change). Given these evolutionary patterns, one should be able to answer the following questions: have troglobitic taxa kept the ancestral states of the characters or not? And have character modifications co-occurred with cave colonisation? Such an analysis can be achieved only by using the method of phylogenetic inference, which consists in using a phylogeny, built according to cladistics, to reconstruct the ancestral states and the evolutionary transformations of taxa features (Andersen, 1979, 1994; Wanntorp et al., 1990; McLennan, 1991; Packer, 1991; Grandcolas et al., 1994; Andersen \& Weir, 1994).

Phylogenetic inference is further employed to test hypotheses in evolutionary biology (Eldrcdge \& Cracraft, 1980; Coddington, 1988, 1990; Carpenter, 1989; Brooks \& McLennan, 1991; Ross \& Carpenter, 1991; Grandcolas et al., 1994, 1997), by comparing the transformation pattern an evolutionary hypothesis predicted with the phylogenetic pattern derived from cladistic analyses: if both patterns fit, the hypothesis is corroborated in the case under study; on the reverse, if both patterns do not fit, the hypothesis is invalidated. The comparison, by analogy, of as many case studies as possible may allow to generalise the tested hypothesis, to modify it or to reject it.

There is a growing number of studies in comparative biology that use phylogenetic inference to reanalyse a large array of evolutionary problems (Andersen, 1979, 1994; Coddington, 1988, 1990; Carpenter, 1989; Wanntorp et al., 1990; Packer, 1991; Ross \& Carpenter, 1991; Siddall et al., 1993; Desutter-Grandcolas, 1993, 1994b, 1996b, 1997b; Grandcolas, 1993, 1996, 1997b; Grandcolas \& Deleporte, 1996; Andersen \& Weir, 1994; Siddall \& Burreson, $1995 ; \ldots)$. Troglobitic evolution is beginning to be reanalysed that way. Current hypotheses of the factors responsible for cave life evolution (Desutter-Grandcolas \& Grandcolas, 1996) and, more generally, the main concepts of current theory of troglobitic evolution (Desutter-Grandcolas, $1997 \mathrm{c}$, have been reevaluated using phylogenetic inference.

I will present here a phylogenetic analysis of the troglobiomorphosis hypothesis in the cricket clade Amphiacustae. This clade has previously been studied for habitat evolution (Desutter-Grandcolas, 1993, 1994b) and for the evolution of wings and stridulatory apparatus in males (DesutterGrandcolas, 1995a, 1997d): it has then been shown that cave colonisation and wing modification did not co-occur and that the loss of acoustic communication did not appear subsequently to cave colonisation. These results partly invalidated the hypothesis of troglobiomorphosis. I will here resume 
this troglobiomorphic analysis and test for the evolution of body coloration, eye size and hindleg size in the Amphiacustae.

\section{MATERIAL AND METHOD}

\section{Material}

The Amphiacustae are distributed in Central America and in the West Indies (Desutter-Grandcolas, 1993). The monophyly and internal phylogeny of this clade have been assessed by the cladistic analyses of morphoanatomical characters (Desutter-Grandcolas, op. cit. and Fig. 1A). The phylogeny was worked out at the genus level, each genus being defined as a monophyletic entity. The present analyses were then achieved at this same level, and 67 species (253 specimens) over the 69 described up to now in this clade have been taken into consideration to precisely define the traits (cf. infra) of each genus (Desutter-Grandcolas, 1993. 1994a. 1995b, 1997e; Desutter-Grandcolas \& Otte, 1997).

The habitats of the taxa have been assessed in a previous paper using data found in the literature and personal observations in the field (see Desutter-Grandcolas, 1993). Two different habitats were then defined: 1/ straminicolous - cavicolous (epigean) and $2 /$ troglobitic. Only one parsimonious scenario was derived to account for habitat distribution among the Amphiacustae: it implied two independent evolutions toward a subterranean life and one reversal toward an epigean way of life (Desutter-Grandcolas, 1993, 1994b, 1997c and Fig. 1B).
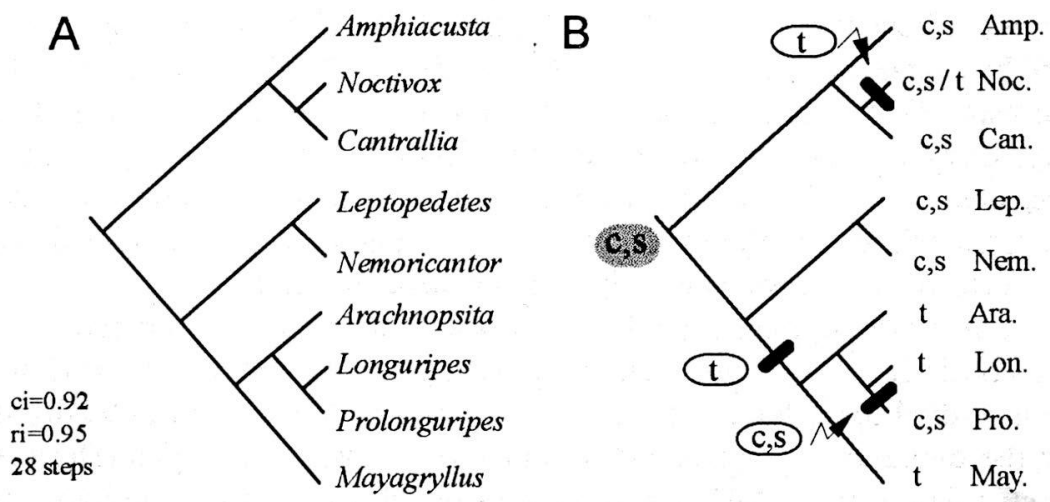

Fig. 1 - Phylogeny (A) of Amphiacustae and reconstructed scenario (B) of their habitat evolution (modified from Desutter-Grandcolas, 1993, 1994b). Ancestral state in a grey frame; attribute change indicated by a large bar and a white frame. 
All the genera were found homogeneous for their habitat, except Noctivox. In the present paper, the following taxa were then considered in the character analyses: 1/ epigean taxa: Amphiacusta, Cantrallia, Leptopedetes, Nemoricantor, epigean Nocrivox (Noct. epig.) and Prolonguripes; 2/ troglobitic taxa: Arachnopsita, Longuripes, Mayagryllus and troglobitic Noctivox (Noct. troglo, including two closely related taxa). The internal phylogeny of Noctivox being still unknown, the subdivision of Noctivox used here in character analyses was not taken into account as such in the Amphiacustae cladogram.

\section{Method for troglobiomorphosis analysis}

In order to test the hypotheses of troglobiomorphosis, several traits have been considered, namely the body coloration, the size of the eye and that of the hindlegs. None had been incorporated in the data matrix used to build the phylogeny of Amphiacustae for lack of reasonable argument to assess primary homology (De Finna, 1991). For each trait, several states have been defined in the taxa under study and mapped onto the Amphiacustae phylogeny (optimisation procedure), using Wagner parsimony extended to multistate traits (Farris, 1970; Fitch, 1971). Hypotheses of the ancestral states of the traits and of their subsequent transformations were thus derived and compared with the patterns implied by troglobiomorphosis hypotheses (Carpenter, 1989; Brooks \& McLennan, 1991; Grandcolas et al., 1994).

\section{Attributes and attribute states definitions}

States of the features analysed here are the following (Table 3):

1/ Body coloration: d, dark; p, pale. All the groups considered in the analysis are homogeneous for this character.

2/ Eye size: 1, large; s, small. All the groups considered in the analysis are homogeneous for this character (Fig. 2-11).

3/ Relative size of hindlegs. Two ratios have been used to account for hindieg size: rat1: Length of hindfemur / Length of the pronotum, and rat2: Length of hindtibia / Length of the pronotum.

The length of the pronotum is considered a good indicator of the size of a specimen, rather than its width, which appears influenced by the presence and development of the wings, and rather than the whole body length, which is sensitive to the actual condition of the specimens (dry or in alcohol) and to their physiological state when collected (especially for females). 

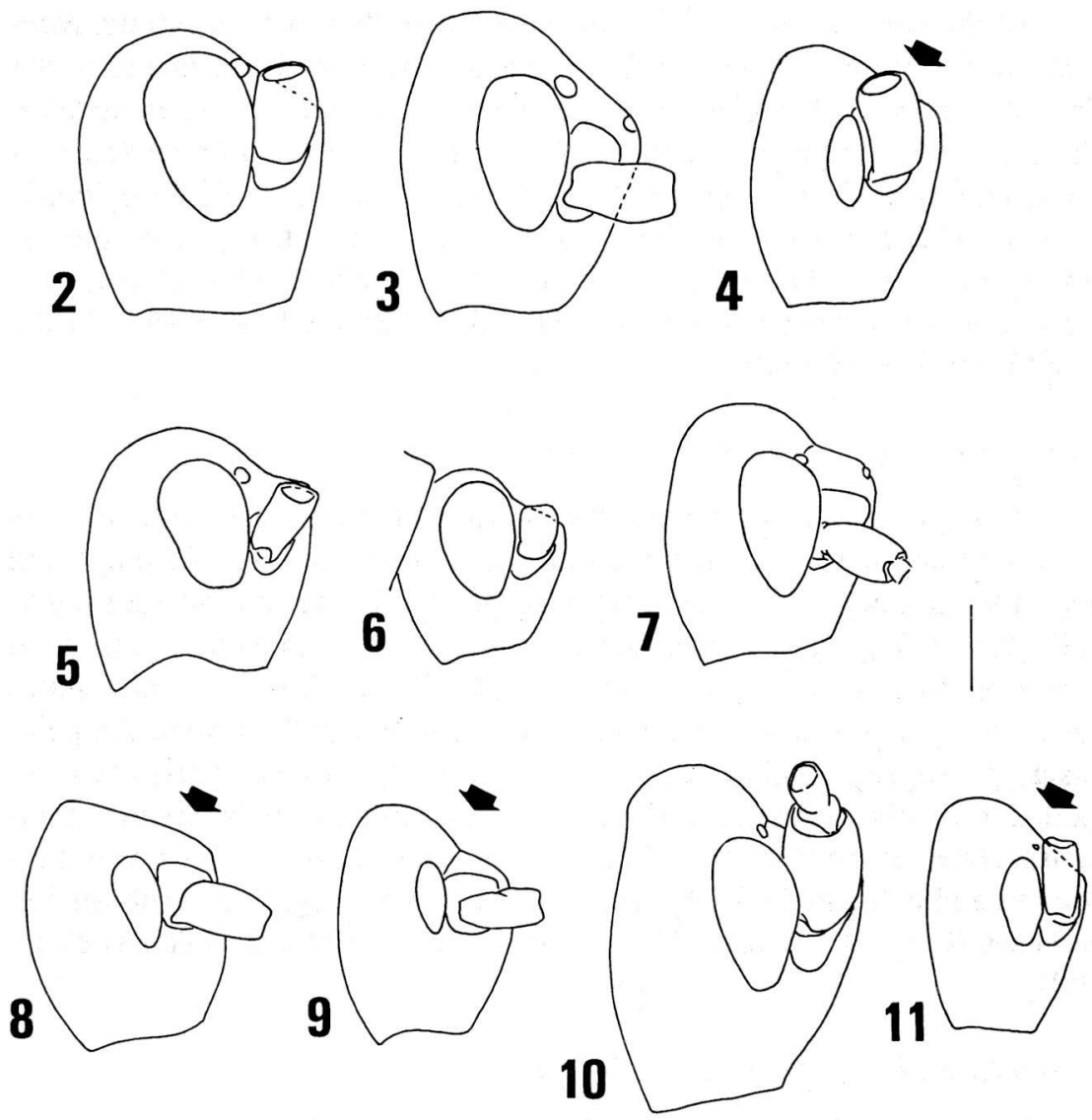

Figs. 2-11 - Heads of amphiacust taxa (right lateral view) showing the eye size. 2, Amphiacusta annulipes; 3 , Noctivox sanchezi; $4, N$. bolivari; 5 , Cantrallia huasteca; 6 , Leptopedetes chiriquensis; 7, Nemoricantor aztecus; 8, Arachnopsita usumacinta; 9, Longuripes sbordonii; 10 , Prolonguripes giganteus; 11, Mayagryllus apterus. Scale $1 \mathrm{~mm}$. Troglobitic taxa identified with a black arrow.

Ratio values were computed directly using the measurements of each specimen and not only the minimum, maximum and mean values indicated in the descriptions of the species (DesutterGrandcolas, 1993, 1994a, 1995b, 1997e; Desutter-Grandcolas \& Otte, 1997).

Both rat 1 and rat 2 are continuous variables. To define the states of each attribute, I performed two-sample Wilcoxon tests between pairs of taxa, with a confidence interval of $95 \%$. These analyses clustered together the taxa for which ratio value distributions have close median values. Tables 1 
and 2 show the results of these tests for rat 1 and rat2. According to these results, the following states were defined for these features:

rat1: 4 states are defined, clustering the following taxa:

state a: Cantrallia.

state b: Amphiacusta, Arachnopsita, Noct. troglo, Mayagryllus.

state c: Nemoricantor, Noct. epig.

state d: Leptopedetes, Longuripes, Prolonguripes.

Figure 12 shows the relative values of theses states. The ratios are higher from a to $\mathrm{d}$, indicating a bigger hindfemur size.

rat2: 4 states are defined, clustering the following taxa:

state a: Cantrallia.

state b: Amphiacusta.

state c: Arachnopsita, Noct. troglo and Noct. epig.

Mayagryllus and Nemoricantor present slightly different ratio value distributions and ambiguously cluster with the preceding taxa; they are indicated as (c) in Table 3.

state d: Leptopedetes Longuripes, Prolonguripes.

Figure 13 shows the relative values of theses states. The ratios are higher from a to d, indicating a bigger hindtibia size.

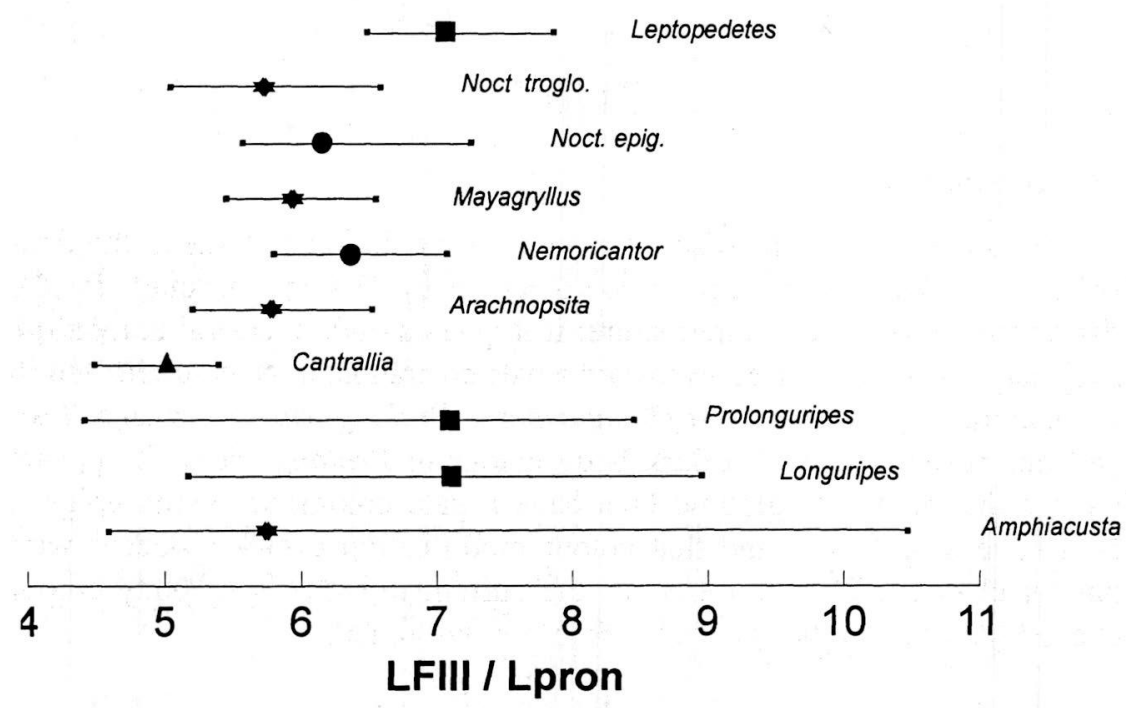

Fig. 12 - Attribute LFIII / Lpron: minimum, maximum and mean values for each taxon, and states used in the phylogenetic analyses. Symbols: $\boldsymbol{\Delta}$ : state a; $*$ state b; $;$ state c; $\mathbf{\square}$ state d. Explanations see text. 


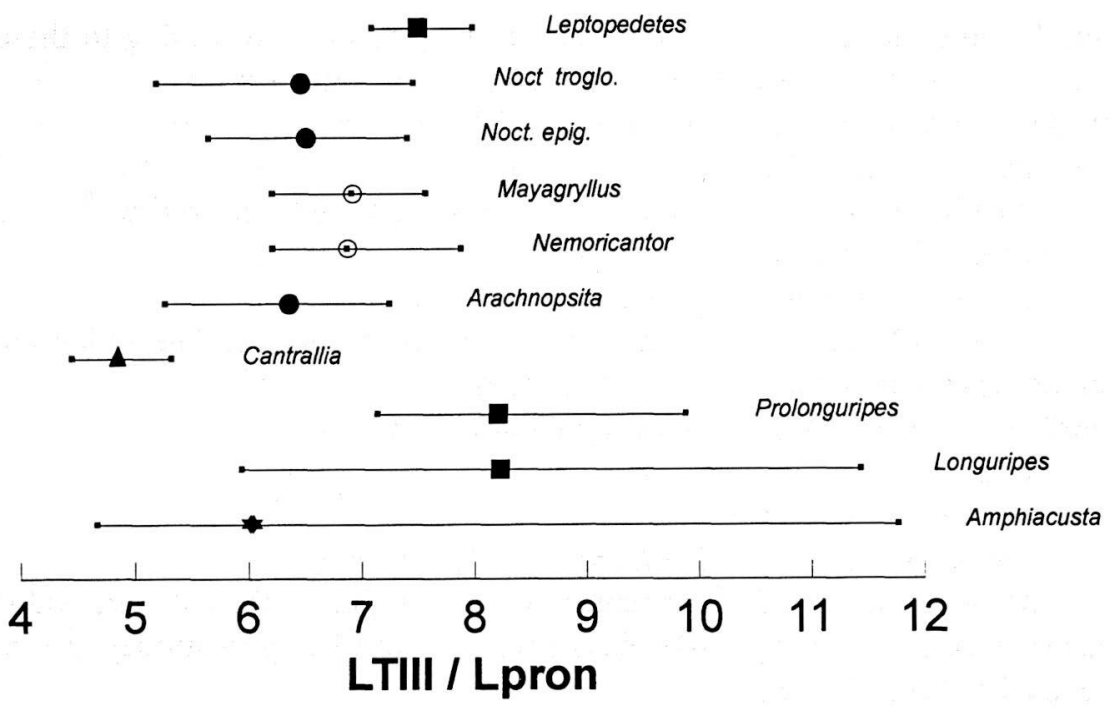

Fig. 13 - Attribute LTIII / Lpron: minimum, maximum and mean values for each taxon, and states used in the phylogenetic analyses. Symbols: $\boldsymbol{\Delta}$ : state a; *: state b; $\bullet$ : state c; $\boldsymbol{\square}$ state d. The symbol $O$ represents ambiguous values of state $c$. Explanations see text.

\section{RESULTS}

\section{1/ Body coloration}

Figure 14 shows the distribution of body coloration states in the Amphiacustae. Only one most parsimonious scenario (3 steps) accounts for the distribution of this two-state feature: it implies a dark ancestral coloration, two independent modifications toward a pale coloration, in Noct. troglo and in the subgroup [(Arachnopsita (Longuripes - Prolonguripes) Mayagryllus], and one reversal toward a dark body colour in Prolonguripes. It appears clearly that all the troglobitic taxa have a pale coloration, while epigean taxa have a dark one, and that colour modification events co-occur with habitat changes. This corroborates the current hypothesis of body colour change (paler coloration) in subterranean environment.

\section{2/ Size of the eyes}

Figure 15 shows the distribution of eye size states in Amphiacustae. As for body coloration only one most parsimonious scenario (3 steps) accounts 
for this distribution: it implies two independent reductions of eye size, in Noct. troglo and in the subgroup [(Arachnopsita (Longuripes - Prolonguripes) Mayagryllus], and one reversal toward a larger eye size in Prolonguripes. As for body colour, these modifications co-occur with habitat change and corroborate the current hypothesis of eye size reduction in subterranean environment.

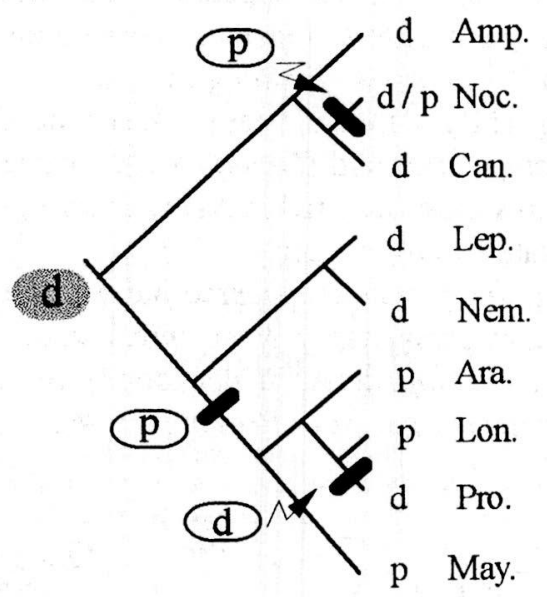

Fig. 14 - Phylogenetic scenario for body coloration. States: d: dark; p: pale. Names of the taxa and symbols as in Fig.1.

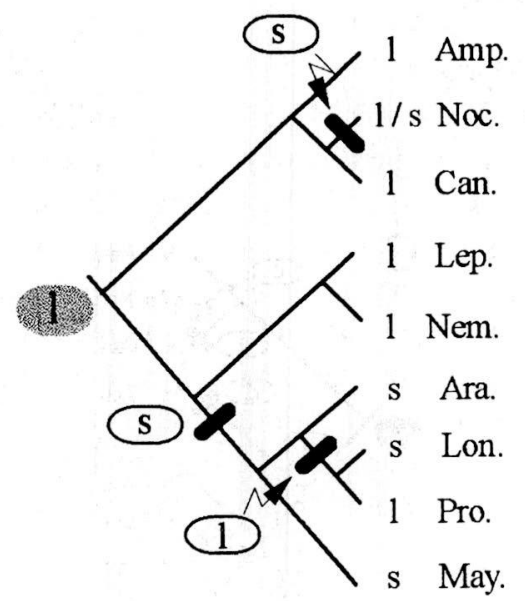

Fig. 15 - Phylogenetic scenario for eye size. States: s: small; 1: large. Names of the taxa and symbols as in Fig.1. 
3/Size of hindleg: ratl (LFIII/Lpron)

Three most parsimonious scenarios (5 steps) account for the distribution of rat1 states in Amphiacustae (Fig. 16). They all imply that $b$ is the ancestral state and that state a occurred in Cantrallia; they moreover show convergent changes either toward state $\mathrm{c}$ or toward state $\mathrm{d}$ :

Scenario 1 (Fig. 16A): state c appeared independently in Noct. epig and in Nemoricantor, and state d appeared independently in Leptopedetes and in the subgroup (Longuripes - Prolonguripes).

Scenario 2 (Fig. 16B): state $d$ appeared independently in the subgroups (Longuripes - Prolonguripes) and (Leptopedetes - Nemoricantor), and one subsequent change to state c occurred in Nemoricantor, independently from the appearance of state $\mathrm{c}$ in Noct. epig.

Scenario 3 (Fig. 16C): state c appeared independently in the subgroup (Leptopedetes - Nemoricantor) and in Noct. epig. and one subsequent change to state d occurred in Leptopedetes, independently from the appearance of state $\mathrm{d}$ in the subgroup (Longuripes - Prolonguripes).
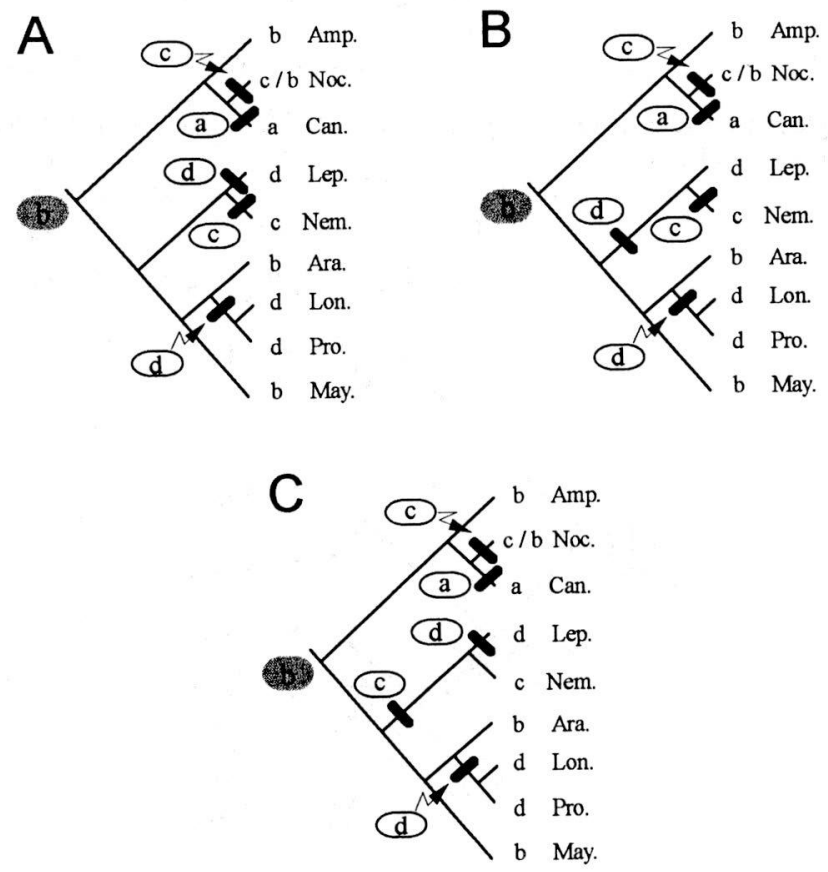

Fig. 16 - Phylogenetic scenarios for hindleg size: LFIII / Lpron. States: see text and Fig. 12. Names of the taxa and symbols as in Fig. 1 . 
These scenarios show that the evolution of rat1 in Amphiacustae has been complex and that it did not follow cave colonisation. State $\mathrm{d}$ thus exists on one hand in the epigean genus Leptopedetes, and on the other hand in the troglobitic genus Longuripes and its epigean sister genus Prolonguripes. On the reverse, the troglobitic species of Noctivox have kept the ancestral state of rat1, while the epigean species of this same taxon have evolved toward a higher ratio. The troglobitic taxa Mayagryllus and Arachnopsita have also kept the ancestral state of rat 1 .

\section{4/Size of hindleg: rat2 (LTIII / Lpron)}

Only one most parsimonious scenario (4 steps) accounts for the distribution of rat2 states in Amphiacustae (Fig. 17). It implies that the ancestral state is state c, and that the following changes have occurred: state b appeared in Amphiacusta, state a in Cantrallia, and state d independently in Leptopedetes and in the subgroup (Longuripes - Prolonguripes).

If states $\mathrm{C}$ and (c) were considered different, the situation would be more complex, with several possible scenarios (6 steps each), the ancestral state being either b, $\mathrm{c}$ or $\mathrm{d}$. The conclusions concerning the evolutionary tendencies of rat 2 would anyhow be similar.

As for rat1, the hypothesis of troglobiomorphosis is not supported by the reconstructed scenario for rat2. The highest ratio (state d) thus appeared independently in the epigean Leptopedetes, and in the troglobitic genus Longuripes and its epigean sister genus Prolonguripes. On the reverse, other troglobitic Amphiacustae kept the ancestral state of rat2 (Noctivox p.p., Arachnopsita), or present a slight modification of this state (Mayagryllus).

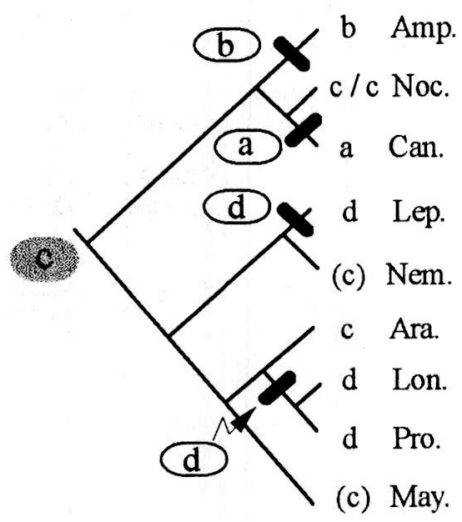

Fig. 17 - Phylogenetic scenario for hindleg size: LTIII / Lpron. States: see text and Fig. 13. Names of the taxa and symbols as in Fig. 1 . 
Table 1 - Two-sample Wilcoxon tests for the attribute LFIII / Lpron. Explanations: see text.

\begin{tabular}{|c|c|c|c|c|c|c|c|c|c|}
\hline LFIII/Lpron & Longuripes & Prolonguripes & Cantrallia & Arachnopsita & Nemoricantor & Mayagryllus & Leptopedetes & Noct. epig. & Noct. troglo \\
\hline Amphiacusta & $\begin{array}{l}W=1856.0 \\
p=0.0000\end{array}$ & $\begin{array}{l}W=1639.0 \\
p=0.0000\end{array}$ & $\begin{array}{l}W=2293.5 \\
p=0.0010\end{array}$ & $\begin{array}{c}W=2215.5 \\
p=0.253 \\
\text { NS at } 0.05\end{array}$ & $\begin{array}{l}W=1675.0 \\
p=0.0041\end{array}$ & $\begin{array}{c}W=2046.5 \\
p=0.061 \\
\text { NS at } 0.05\end{array}$ & $\begin{array}{l}W=1565.0 \\
p=0.0007\end{array}$ & $\begin{array}{l}W=1947.5 \\
p=0.0037\end{array}$ & $\begin{array}{l}W=1984.0 \\
p=0.5181 \\
\text { NS at } 0.05\end{array}$ \\
\hline Longuripes & & $\begin{array}{l}W=1605.0 \\
p=0.7577 \\
N S \text { at } 0.05\end{array}$ & $\begin{array}{l}W=2169.0 \\
p=0.0000\end{array}$ & $\begin{array}{l}W=2626.5 \\
p=0.0000\end{array}$ & $\begin{array}{l}W=1707.0 \\
p=0.0033\end{array}$ & $\begin{array}{l}W=2423.0 \\
p=0.0000\end{array}$ & $\begin{array}{c}W=1437.5 \\
p=0.7506 \\
N S \text { at } 0.05\end{array}$ & $\begin{array}{l}W=2349.0 \\
p=0.0000\end{array}$ & $\begin{array}{l}W=2114.5 \\
p=0.0000\end{array}$ \\
\hline Prolonguripes & & & $\begin{array}{l}W=339.0 \\
p=0.0000\end{array}$ & $\begin{array}{l}W=480.0 \\
p=0.0000\end{array}$ & $\begin{array}{l}W=231.0 \\
p=0.0079\end{array}$ & $\begin{array}{l}W=429.0 \\
p=0.0000\end{array}$ & $\begin{array}{l}W=152.0 \\
p=0.7105 \\
N S \text { at } 0.05\end{array}$ & $\begin{array}{l}W=415.0 \\
p=0.0001\end{array}$ & $\begin{array}{l}W=336.0 \\
p=0.0001\end{array}$ \\
\hline Cantrallia & & & & $\begin{array}{l}W=191.5 \\
p=0.0000\end{array}$ & $\begin{array}{l}W=171.0 \\
p=0.0000\end{array}$ & $\begin{array}{l}W=171.0 \\
p=0.0000\end{array}$ & $\begin{array}{l}W=171.0 \\
p=0.0000\end{array}$ & $\begin{array}{l}W=171.0 \\
p=0.0000\end{array}$ & $\begin{array}{l}W=197.0 \\
p=0.0000\end{array}$ \\
\hline Arachnopsita & & & & & $\begin{array}{l}W=481.0 \\
p=0.0006\end{array}$ & $\begin{array}{l}W=695.5 \\
p=0.0783 \\
N S \text { at } 0.05\end{array}$ & $\begin{array}{l}W=436.0 \\
p=0.0002\end{array}$ & $\begin{array}{l}W=610.0 \\
p=0.0012\end{array}$ & $\begin{array}{c}W=713.5 \\
p=0.7099 \\
\text { NS at } 0.05\end{array}$ \\
\hline Nemoricantor & & & & & & $\begin{array}{l}W=280.5 \\
p=0.0086\end{array}$ & $\begin{array}{c}W=75.0 \\
p=0.0182\end{array}$ & $\begin{array}{l}W=239.0 \\
p=0.2294 \\
\text { NS at } 0.05\end{array}$ & $\begin{array}{l}W=240.0 \\
p=0.0008\end{array}$ \\
\hline Mayagryllus & & & & & & & $\begin{array}{l}W=326.0 \\
p=0.0002\end{array}$ & $\begin{array}{l}W=530.5 \\
p=0.0388\end{array}$ & $\begin{array}{c}W=629.0 \\
p=0.0533 \\
\text { NS at } 0.05\end{array}$ \\
\hline Leptopedetes & & & & & & & & $\begin{array}{l}W=160.0 \\
p=0.0015\end{array}$ & $\begin{array}{l}W=127.0 \\
p=0.0006\end{array}$ \\
\hline Noct. epig. & & & & & & & & & $\begin{array}{l}W=678.5 \\
p=0.0016\end{array}$ \\
\hline
\end{tabular}

Table 2 - Two-sample Wilcoxon tests for the attribute LTIII / Lpron. Explanations: see text.

\begin{tabular}{|c|c|c|c|c|c|c|c|c|c|}
\hline LFIII/Lpron & Longuripes & Prolonguripes & Cantrallia & Arachnopsita & Nemoricantor & Mayagryllus & Leptopedetes & Noct. epig. & Noct. troglo \\
\hline Amphiacusta & $\begin{array}{l}W=1524.0 \\
p=0.0000\end{array}$ & $\begin{array}{l}W=1368.0 \\
p=0.0000\end{array}$ & $\begin{array}{l}W=2162.5 \\
p=0.0000\end{array}$ & $\begin{array}{l}W=1769.0 \\
p=0.0056\end{array}$ & $\begin{array}{l}W=1431.0 \\
p=0.0013\end{array}$ & $\begin{array}{l}W=1512.0 \\
p=0.0000\end{array}$ & $\begin{array}{l}W=1347.0 \\
p=0.0023\end{array}$ & $\begin{array}{l}W=1660.0 \\
p=0.0008\end{array}$ & $\begin{array}{l}W=1554.0 \\
p=0.0083\end{array}$ \\
\hline Longuripes & & $\begin{array}{l}W=1739.0 \\
p=0.9687 \\
N S \text { at } 0.05\end{array}$ & $\begin{array}{l}W=2314.0 \\
p=0.0000\end{array}$ & $\begin{array}{l}W=2771.0 \\
p=0.0000\end{array}$ & $\begin{array}{l}W=1875.0 \\
p=0.0001\end{array}$ & $\begin{array}{l}W=2528.0 \\
p=0.0000\end{array}$ & $\begin{array}{c}W=1568.0 \\
p=0.0933 \\
\text { NS at } 0.05\end{array}$ & $\begin{array}{l}W=2607.5 \\
p=0.0000\end{array}$ & $\begin{array}{l}W=2172.5 \\
p=0.0000\end{array}$ \\
\hline Prolonguripes & & & $\begin{array}{l}W=357.0 \\
p=0.0000\end{array}$ & $\begin{array}{l}W=493.0 \\
p=0.0000\end{array}$ & $\begin{array}{l}W=247.0 \\
p=0.0004\end{array}$ & $\begin{array}{l}W=437.0 \\
p=0.0000\end{array}$ & $\begin{array}{l}W=160.0 \\
p=0.0710 \\
\text { NS at } 0.05\end{array}$ & $\begin{array}{l}W=449.0 \\
p=0.0000\end{array}$ & $\begin{array}{l}W=326.0 \\
p=0.0000\end{array}$ \\
\hline Cantrallia & & & & $\begin{array}{l}W=172.0 \\
p=0.0000\end{array}$ & $\begin{array}{l}W=171.0 \\
p=0.0000\end{array}$ & $\begin{array}{l}W=171.0 \\
p=0.0000\end{array}$ & $\begin{array}{l}W=171.0 \\
p=0.0009\end{array}$ & $\begin{array}{l}W=171.0 \\
p=0.0000\end{array}$ & $\begin{array}{l}W=173.0 \\
p=0.0000\end{array}$ \\
\hline Arachnopsita & & & & & $\begin{array}{l}W=490.5 \\
p=0.0313\end{array}$ & $\begin{array}{l}W=546.0 \\
p=0.0002\end{array}$ & $\begin{array}{l}W=410.0 \\
p=0.0010\end{array}$ & $\begin{array}{c}W=714.5 \\
p=0.4651 \\
N S \text { at } 0.05\end{array}$ & $\begin{array}{c}W=614.0 \\
p=0.7053 \\
\text { NS at } 0.05\end{array}$ \\
\hline Nemoricantor & & & & & & $\begin{array}{l}W=189.0 \\
p=0.6307 \\
N S \text { at } 0.05\end{array}$ & $\begin{array}{c}W=75.0 \\
p=0.0414\end{array}$ & $\begin{array}{c}W=254.5 \\
p=0.0829 \\
\text { NS at } 0.05\end{array}$ & $\begin{array}{l}W=190.0 \\
p=0.0798 \\
\text { NS at } 0.05\end{array}$ \\
\hline Mayagryllus & & & & & & & $\begin{array}{l}W=345.0 \\
p=0.0194\end{array}$ & $\begin{array}{l}W=800.5 \\
p=0.0016\end{array}$ & $\begin{array}{l}W=644.0 \\
p=0.0015\end{array}$ \\
\hline Leptopedetes & & & & & & & & $\begin{array}{l}W=134.0 \\
p=0.0018\end{array}$ & $\begin{array}{c}W=92.0 \\
p=0.0026\end{array}$ \\
\hline Noct. epig. & & & & & & & & & $\begin{array}{l}W=523.0 \\
p=0.9680 \\
\text { NS at } 0.05\end{array}$ \\
\hline
\end{tabular}


Table 3 - Distributions of the states of the features studied in this paper. Explanations: see text.

\begin{tabular}{lcccc}
\hline & Body colour & eye size & LFIII / Lpron & LTIII / Lpron \\
\hline Amphiacusta & dark & large & $\mathrm{b}$ & $\mathrm{b}$ \\
Longuripes & pale & small & $\mathrm{d}$ & $\mathrm{d}$ \\
Prolonguripes & dark & large & $\mathrm{d}$ & $\mathrm{d}$ \\
Cantrallia & dark & large & $\mathrm{a}$ & $\mathrm{a}$ \\
Arachnopsita & pale & small & $\mathrm{b}$ & $\mathrm{c}$ \\
Nemoricantor & dark & large & $\mathrm{c}$ & $(\mathrm{c})$ \\
Mayagryllus & pale & small & $\mathrm{b}$ & $(\mathrm{c})$ \\
Leptopedetes & dark & large & $\mathrm{d}$ & $\mathrm{d}$ \\
Noct. epig. & dark & large & $\mathrm{c}$ & $\mathrm{c}$ \\
Noct. troglo. & pale & small & $\mathrm{b}$ & $\mathrm{c}$ \\
\hline
\end{tabular}

\section{DISCUSSION}

The phylogenetic analyses presented in this paper partly corroborate and partly refute the hypothesis of troglobiomorphosis. In both cases however the patterns of change of attribute states reveal that homoplasies (convergence, reversal) frequently occur in the case under study: these could not have been documented in a non phylogenetic context, for lack of independent argument to assess attribute change polarity (Carpenter, 1989; McLennan, 1991; Grandcolas et al., 1994; Desutter-Grandcolas, 1997c).

In the present analyses, some attribute states are present only in troglobitic Amphiacustae and their evolutionary transformations co-occurred with habitat changes in this clade: they appeared in the taxa which have shifted toward a subterranean habitat (troglobitic Noctivox species and the subclade [Arachnopsita - Mayagryllus]) and reversed toward an ancestral state in the taxa which have returned toward an epigean habitat (Prolonguripes). Such is the case of a reduced eye size and of a pale body coloration (Fig. 14, 15). The polarity of change for the eye size and the body coloration attributes corroborates the troglobiomorphosis hypothesis.

Conversely, other characters show complex evolutionary transformation series and no simple relation with habitat changes can be found. This is the case of the two attributes used to characterise hindleg size (rat1 and rat2). The phylogenetic patterns derived from cladistic analyses for these attributes showed that neither a shift toward a subterranean habitat nor a reversal toward an epigean life is obligatorily accompanied by a modification of these attribute states, contrary to what is observed for eye size and body coloration. Increase of hindleg size may actually happen in troglobitic taxa, just as it may occur in epigean taxa. In fact no polarity of change seems as- 
sociated with habitat modifications, which invalidates the troglobiomorphosis hypothesis. As already indicated above, a similar refutation resulted from the phylogenetic analyses of male forewing and stridulatory apparatus (Desutter-Grandcolas, 1997d): homoplastic changes (convergences) occurred between epigean and troglobitic taxa for the loss of the stridulum, and reversals were documented in both epigean and troglobitic taxa.

In the Amphiacustae, the troglobiomorphic hypothesis is thus corroborated by eye size and body coloration, but invalidated by hindleg size and wing development. Even within a single cricket clade, "troglobiomorphosis" thus concerns a heterogeneous lot of characters, the state distributions and evolutionary transformations of which are diverse and contradictory. No unique pattern of morphological evolution exists. On the contrary, several patterns are derived from the phylogenetic analyses, involving character state diversification and homoplasies (convergence or reversal). Such patterns are commonly documented in phylogenetic reconstructions (Andersen, 1979, 1994; Carpenter, 1989; Coddington, 1990; Wanntorp et al., 1990; Packer, 1991; Desutter-Grandcolas, 1994b, 1997b,d; Andersen and Weir, 1994; Siddall \& Burreson, 1995; Grandcolas, 1993, 1996, 1997b; many contributions in Grandcolas, 1997a) and troglobitic evolution is in this respect not different from other phyletic evolutions.

So-called troglobiomorphic transformations are often considered adaptive to cave life, either directly or through energy economy (Howarth, 1981, 1987; Culver, 1982; Peck, 1990; Kane \& Culver, 1992; Culver et al., 1994). Howarth (1983: 374) thus stated: "Troglobites have evolved to exploit the organic resources found in mesocavernous and macrocavernous habitats. The close similarity of cave adaptations among the diverse taxa in so many different cave areas indicates that cave adaptation is a general process and the result of similar selection pressures" and precised further: "The adaptations displayed by troglobites include loss or reduction of eyes, cuticular pigments, wings, a circadian rhythm, and in some species a functional tracheal system; thinning of cuticule; and often the development of longer appendages, an increase of vestiture, a larger, more slender body form, and in some species a lower metabolism". Other hypotheses, such as the accumulation of neutral mutations, pleiotropic effects or genetic drift, have also been proposed to account for the morphological changes occurring in some cave dwelling organisms (e.g. Culver, 1982; Howarth, 1987; see also Wilkens, 1986, 1992; Rouch \& Danielopol, 1987; Botosaneanu \& Holsinger, 1991) and no single hypothesis seems able to account for the available data (Christiansen, 1992; see also comments in Leroi et al., 1994).

As already indicated, phylogenetic analyses cannot be used to directly test those process hypotheses, because it is not possible to reasonably assess 
that the processes observed in present-day populations are similar to those that were occurring in ancestral populations in ancestral environments (Greene 1986; Leroi et al., 1994). However phylogenetic reconstructions can acurately test for the plausibility of each process hypothesis, by the comparisons of the phylogenetic and predicted patterns: if a process hypothesis implies a given distribution of the states of the character of interest and if this given pattern is different from the pattern reconstructed using phylogeny, then this process hypothesis is refuted in the case under study. This is the most neutral method presently at hand to extend process hypotheses derived from present-day population studies to the past, and to tentatively reconstruct evolutionary pathways: other methods exist, but they are all based on a given set of unwarranted hypotheses which biases and weakens their conclusions (Eldredge \& Cracraft, 1980; Grandcolas et al., 1994, 1997). Such a process analysis is far beyond the aim of this paper for lack of data on Amphiacustae populations. Future studies on troglobiomorphy should however integrate both population studies and phylogenetic analyses (taxonomies have long been recognised inadequate references in historical studies) at the scale of monophyletic groups of taxa including both troglobites and epigean organisms, to achieve such phylogenetic tests of process hypotheses.

\section{CONCLUSION}

The present paper analyses the troglobiomorphosis hypothesis in one given case study and concludes to a complex situation, for which no simple explanation can a priori he found. Could these results be generalised, and if so how? Obligate cave dwelling organisms are morphologically diverse and distantly related (Vandel, 1964; Howarth, 1983; Juberthie \& Decu, 1994). To test for convergent patterns of morphological evolution it would consequently be necessary first to consider separately all the characters that are currently gathered in the "troglobiomorphic syndrome", second to examine their evolutionary transformations in monophyletic clades including both epigean and troglobitic taxa through phylogenetic analyses, and third to compare by analogy the phylogenetic patterns thus reconstructed. This should allow to propose falsifiable hypotheses concerning the effect of cave living on morphological evolution. By contrast, the troglobiomorphosis hypothesis, as formulated today, may be qualified a "conceptual dead-end", as it impedes a real test of the hypotheses of troglobitic morphological modifications. Also its current association with habitat characterization biased studies in troglobitic life by imposing ad hoc hypotheses on basic definitions. 
Our understanding in cave life has been deeply modified these last thirty years, owing to important discoveries on the subterranean world and organisms (Howarth, 1983; Juberthie, 1984; Juberthie \& Decu, 1994). These findings have been easily accepted by Biospeologists and have been followed by a large amount of new, enthusiastic studies.

Now another step in cave life studies is necessary, which concerns the methodology used to analyse troglobitic evolution. Recent increase of knowledge concerning cave life deeply questions traditional ideas on troglobitic evolution. Peck \& Finston (1993) rightly observed that point, but stated: "There may not be a unified theory of troglobitic origin, and this may be a general property of the evolutionary biology of caves". It is clear however that as in any field of Comparative Biology the elaboration of a general theory of cave life origin and cave life evolution, be it with one or several proposals, will result from the independent and reasonable tests of current hypotheses, that is using phylogenetic inference (Eldredge \& Cracraft, 1980). Some authors have rightly foreseen this (Deeleman-Rheinhold, 1981; Peck, 1981). Now that a clear methodology in phylogenetic inference is at hand, let us hope that many studies will be carried out in that direction.

\section{ACKNOWLEDGMENTS}

I thank M. Bologna and V. Sbordoni for the opportunity to publish this paper, and P. Grandcolas and L. Matile for comments on the manuscripts.

\section{LITERATURE CITED}

ANDERSEN, N.M. 1979. Phylogenetic inference as applied to the study of evolutionary diversification of semiaquatic bugs (Hemiptera: Gerromorpha). Syst. Zool. 28: 554-578.

ANDERSEN, N.M. 1994. The evolution of sexual size dimorphism and mating systems in water strider (Hemiptera; Gerridae): a phylogenetic approach. Ecoscience 1: 208-214.

ANDERSEN, N.M. and T.A. WEIR. 1994. Australobates rivularis, gen. et sp. nov., a freshwater relative of Halobates Eschscholtz (Hemiptera: Gerridae), with a new perspective on the evolution of sea skaters. Invertebr. Taxon. 8: $1-15$.

BARR, T.C. 1968. Cave ecology and evolution of troglobites. Evol. Biol. 2: 35-102.

BARR, T.C. and J.H. HOLSINGER. 1985. Speciation in cave fauna. Annu. Rev. Ecol. Syst. 16: 313-337.

BOTOSANEANU, L. and J.R. HOLSINGER. 1991. Some aspects concerning colonization of the subterranean realm - especially of subterranean waters: a response to Rouch \& Danielopol, 1987. Stygologia 6: 11-39.

BROOKS, DR. and D.A. McLENNAN. 1991. Phylogeny, ecology and behaviour. Univ. Chicago press, Chicago.

CAMACHO, A.I. (ed.) 1992. The natural history of biospeleology. Mus. Nac. Cienc. nat., CSIC, Madrid.

CARPENTER, J.M. 1989. Testing scenarios: wasp social behavior. Cladistics 5: 131-144.

CHRISTIANSEN, K. 1962. Proposition pour la classification des animaux cavernicoles. Spelunca Mem. 2: 76-78. 
CODDINGTON, J.A. 1988. Cladistic tests of adaptational hypotheses. Cladistics 4: 3-22.

CODDINGTON, J.A. 1990. Bridges between evolutionary pattern and process. Cladistics 6: 379-386.

CULVER, D.C. 1982. Cave life evolution and ecology. Harvard univ. Press, Cambridge.

DESUTTER-GRANDCOLAS, L. 1993. The cricket fauna of Chiapanecan caves (Mexico): systematics, phylogeny and the evolution of troglobitic life (Orthoptera, Grylloidea, Phalangopsidae, Luzarinae). Int. J. Speleol. 22: 1-82.

DESUTTER-GRANDCOLAS, L. 1994a. Description des genres Cantrallia et Leptopedetes (Grylloidea, Phalangopsidae, Luzarinae, Amphiacustae). Rev. fr. Entomol. 16: 99-107.

DESUTTER-GRANDCOLAS, L. 1994b. Test phylogénétique de l'adaptation à vie troglobie chez des grillons (Insecta, Orthoptera, Grylloidea). C. R. Acad. Sci. Paris 317: 907-912.

DESUTTER-GRANDCOLAS, L. 1995a. Toward the knowledge of the evolutionary biology of phalangopsid crickets (Orthoptera, Grylloidea, Phalangopsidae): data, questions and scenarios. J. Orth. Res. 4: 163-175.

DESUTTER-GRANDCOLAS, L. 1995b. Nouveaux grillons cavernicoles de la region néotropicale (Orthoptera, Grylloidea, Phalangopsidae). Rev. fr. Entomol. 17: 97-106.

DESUTTER-GRANDCOLAS, L. 1997a (1999). Grylloidea, p. 989-1001. In C. JUBERTHIE and V. DECU (eds), Encyclopaedia biospeologica. II, Société de Biospéologie, Moulis and Bucarest.

DESUTTER-GRANDCOLAS, L. 1997b. Acoustic communication in crickets (Orthoptera: Grylloidea): a model of regressive evolution revisited using phylogeny, p. 183-202. In P. GRANDCOLAS (ed.), The origin of biodiversity in insects: phylogenetic tests of evolutionary scenarios. Mém. Mus. natn. Hist. nat., Paris, 173.

DESUTTER-GRANDCOLAS, L. 1997c. Studies in cave life evolution: a rationale for future theoretical developments using phylogenetic inference. J. zool. Syst. evol. Res. 35: 23-31.

DESUTTER-GRANDCOLAS, L. 1997d. A phylogenetic analysis of the evolution of the stridulatory apparatus in true crickets (Orthoptera, Grylloidea). Cladistics, 13: 101-108.

DESUTTER-GRANDCOLAS, L. 1997e. Descriptions of new Amphiacustae (Orthoptera, Grylloidea, Phalangopsidae). I. Genera Nemoricantor, Arachnopsita, Mayagryllus and Prolonguripes. Ent. Scand. 28: 175-188.

DESUTTER-GRANDCOLAS, L. and P. GRANDCOLAS. 1996. A phylogenetic reappraisal of the theories on the evolution toward troglobitic life. Mém. Biospéol. 23: 57-63.

DESUTTER-GRANDCOLAS, L. and D. OTTE. 1997. Revision of the West Indian genus Amphiacusta Saussure, 1874, with descriptions of 20 new species (Orthoptera: Grylloidea: Phalangopsidae). Annls. Soc. ent. Fr. (N.S.) 33: 101-128.

ELDREDGE, N. and J. CRACRAFT. 1980. Phylogenetic patterns and the evolutionary process. Columbia university press, New York.

FARRIS, J.S. 1970. Methods for computing Wagner trees. Syst. Zool. 19: 83-92.

FITCH, W. M. 1971. Toward defining the course of evolution: minimum change for a specified tree topology. Syst. Zool. 20: 406-416,

GINET, R. and V. DECU. 1977. Initiation à la biologie et à l'écologie souterraines. JeanPierre Delarge, Paris.

GRANDCOLAS, P. 1993. The origin of biological diversity in a tropical cockroach lineage: a phylogenetic analysis of habitat choice and biome occupancy. Acta Oecologica 14: $259-270$.

GRANDCOLAS, P. 1996. The phylogeny of cockroach families: a cladistic appraisal of morphoanatomical data. Can. J. Zool. 74: 508-527.

GRANDCOLAS, P. (ed.) 1997a. The origin of biodiversity in insects: phylogenetic tests of evolutionary sçenarios. Mém. Mus. natn. Hist. nat. 173-354.

GRANDCOLAS, P. 1997b. What did the ancestors of the woodroach Cryptocercus look like? A phylogenetic study of the origin of subsociality in the subfamily Polyphaginae (Dictyoptera, Blattaria), p. 231-252. In P. GRANDCOLAS (ed.) The origin of biodiversity in insects: phylogenetic tests of evolutionary scenarios. Mém. natn. Hist. nat. 173.

GRANDCOLAS, P. and P. DELEPORTE. 1996. The origin of protistan symbionts in termites and cockroaches: a phylogenetic perspective. Cladistics 12: 93-98. 
GRANDCOLAS, P., P. DELEPORTE, and L. DESUTTER-GRANDCOLAS. 1994. Why to use phylogeny in comparative ecology? Acta Oecologica, 15: 661-673.

GRANDCOLAS, P., P. DELEPORTE, and L. DESUTTER-GRANDCOLAS. 1997. Testing evolutionary processes with phylogenetic patterns: test power and test limitations, p. 5371. In P. GRANDCOLAS (ed.) The origin of biodiversity in insects: phylogenetic tests of evolutionary scenarios. Mém. Mus. natn. Hist. nat. 173.

GRANDCOLAS, P., J. MINET, L. DESUTTER-GRANDCOLAS, C. DAUGERON, L. MATILE and T. BOURGOIN. 1997. Linking phylogenetic systematics to evolutionary biology: a research program in biodiversity, p. 341-350. In P. GRANDCOLAS (ed.), The origin of biodiversity in insects: phylogenetic tests of evolutionary scenarios. Mém. Mus. natn. Hist. nat. 173.

HOWARTH, F.G. 1981. Non-relictual terrestrial troglobites in the tropical Hawaiian caves. Proc. 8th. Int. Congr. Speleol., Bowling Green, KY, 2: 539-541.

HOWARTH, F.G. 1983. Ecology of cave Arthropods. Annu. Rev. Entomol. 28: 365-389.

HOWARTH, F.G. 1987. The evolution of non-relictual tropical troglobites. Int. J. Speleol. 16: 1-16.

JUBERTHIE, C. and V. DECU. 1994. Encyclopaedia biospeologica. I. Société de Biospéologie, Moulis and Bucarest.

LEROI, A.M., M.R. ROSE, and G.V. LAUDER. 1994. What does the comparative method reveal about adaptation? Am. Nat. 143: 381-402.

LEROY, Y. 1967. Gryllides et Gryllacridides cavernicoles. Ann. Spéléol. 22: 659-722.

LINCOLN, R.J., G.A. BOXSHALL, and P.F. CLARK. 1982. A dictionary of ecology, evolution and systematics. Cambridge univ. Press, Cambridge.

MATILE, L. 1994. Diptera, p. 341-357. In C. JUBERTHIE and V. DECU (eds), Encyclopaedia biospeologica. I, Société de Biospéologie, Moulis and Bucarest.

McLENNAN, D.A. 1991. Integrating phylogeny and experimental ethology: from pattern to process. Evolution 45: 1773-1789.

PACKER, L. 1991. The evolution of social behavior and nest architecture in sweat bees of the subgenus Evylaeus (Hymenoptera: Halictidae): a phylogenetic perspective. Behav. Ecol. Sociobiol. 29: 153-160.

PECK, S.B. 1981. The geological, geographical and environnemental setting of cave fauna evolution. Proc. 8th. Int. Congr. Speleol., Bowling Green, KY, 2: 501-502.

PECK, S.B. 1990. Eyeless Arthropods of the Galapagos islands, Ecuador: composition and origin of the Cryptozoic fauna of a young, tropical, oceanic archipelago. Biotropica 22: 366-381.

PECK, S.B. and T.L. FINSTON. 1993. Galapagos islands troglobites: the questions of tropical troglobites, parapatric distribution with eyed-sister-species, and their origin by parapatric speciation. Mém. Biospéol. 20: 19-37.

De PINNA, M.C.C. 1991. Concepts and tests of homology in the cladistic paradigm. Cladistics 7: 367-394.

RACOVITZA, E.-G. 1907. Essai sur les problèmes biospéologiques. Arch. Zool. exp. gen. 4: 371-488.

ROSS, K.G. and J.M. CARPENTER. 1991. Phylogenetic analysis and the evolution of queen number in eusocial Hymenoptera. J. evol. Biol. 4: 117-130.

SCHINER, J.-R. 1854. Fauna der Adelsberger, Lueger und Magdalener-Grotte, p. 231-272. In A. SCHMIDL (ed.), Die Grotten und Hohlen von Adelsberg, Lueg, Planina und Loos. Braunmuller, Wien.

SIDDALL, M.E., D.R. BROOKS, and S.S. DESSER. 1993. Phylogeny and the reversibility of parasitism. Evolution 47: 308-313.

SIDDALL, M.E. and BURRESON, E.M. 1995. Phylogeny of the Euhirudinea: independent evolution of blood feeding by leeches? Can. J. Zool. 73: 1048-1064.

THIBAUD, J.M. 1994. For a biological and ecological classification of cavernicolous Collembola (Hexapoda). Mém. Biospéol. 21: 147-149.

VANDEL, A. 1964. Biospéologie. La biologie des animaux cavernicoles. Gauthier-Villars, Paris.

WANNTORP, H.E., D.R. BROOKS, T. NILSSON, S. NYLIN, F. RONQUIST, S.C. STEARNS, and N. WEDELL. 1990. Phylogenetic approaches in ecology. Oikos 57: 119-132. 